JANA VLČKOVÁ

\title{
CAN EXPORTS BE USED AS AN INDICATOR OF TECHNOLOGICAL CAPABILITIES OF COUNTRIES?
}

\begin{abstract}
VLČKOVÁ, J. (2015): Can exports be used as an indicator of technological capabilities of countries? Geografie, 120, No. 3, pp. 314-329. - During the past 30 years, many emerging economies, especially China, have strengthened their technological and innovative capabilities. Have these countries started to threaten the position of traditional technological leaders? This paper examines whether technological capabilities of an economy can be evaluated based on the goods each economy exports (EXPY). Detailed product classification of exports to the EU in the period between 1984 and 2009 form the underlying data. Further, other data and studies are used to assess the reliability of EXPY. Results show that many emerging economies have significantly increased their technological sophistication; among them exports of Mexico, the Philippines and Malaysia are technologically the most sophisticated. These economies have significant share of foreign value added embodied in exports, though. Therefore, EXPY based on gross exports is not a reliable indicator of technological capabilities of countries and this indicator needs to be combined with other data.
\end{abstract}

KEY WORDS: technology sophistication - EXPY - exports - EU - emerging economies.

\section{Introduction}

Differences in the wealth of countries and uneven economic development have been attributed to differences in technological upgrading and productivity (Romer 1990; Krugman 1991; Grossman, Helpman 1991). The rapid growth of a series of new global players, especially China and India, has heightened competition among the world's economies and forced many to reconsider where their competitive advantage now lie. As some newly developing economies increase their innovative capacity and upgrade their technologies, is the technological leadership of developed countries and the core of their competitive advantage in jeopardy?

Still, the innovation potential and technological capabilities of emerging economies remain in dispute. On the one hand, thanks to globalization and higher levels of economic integration and technology transfer between developed and developing economies, emerging economies face unprecedented opportunities to exploit global knowledge resources. On the other hand, knowledge, especially the most valuable, tacit variety remains geographically localized and relatively immobile (Jaffe, Trajtenberg, Henderson 1993; Saxenian 1996; Gertler 2007). A precise estimation of the technological sophistication of countries is problematic because technology cannot be directly measured. Many proxies have been used in order to measure technology like total factor 
productivity, R\&D expenditures, patents and citations, however, the precision of these proxies is unclear (Altenburg, Schmitz, Stamm 2008).

The aim of this paper is to examine whether a relatively new measure of macroeconomic technological capacity, the EXPY proposed by Hausmann, Hwang, Rodrik (2007), can be used to explore the technological capabilities of countries. So far, most studies focused on the exports to the US or to the whole world (e.g. Hausmann, Hwang, Rodrik 2007; CEPII 2012). Using exports to the EU enables me to assess whether there are differences between EXPY based on exports to the whole world or the US and the EU. Firstly, I will examine differences in the technological levels among countries in general during the observed period and compare them to other data in order to assess the reliability of the indicator EXPY. Secondly, I will compare the results with other studies based on EXPY. Analysis here will focus on exports to the EU15 between 1984 and 2009. EXPY is calculated for all countries for which export data to the EU and GDP per capita data were available (ranging from 120-150 countries). Detailed trade data in the SITC 4 digit classification have been used to calculate the EXPY (circa 820 products).

The paper proceeds as follows. In Section 2, I will provide a brief review of the role of technology in economic growth and the connection between technology and trade. Section 3 will focus on the data used for this analysis, along with a discussion of the method for measuring EXPY. Section 4 will present the results of the analysis and will offer comparisons to related data and studies. Section 5 will conclude the paper.

\section{Economic growth, technology and trade}

From Marx, through Schumpeter (1947), to Solow (1956) and new endogenous growth theorists, Romer (1990) and Lucas (1988), technology has long been considered the foundation of growth. However, until quite recently, technology was largely considered as a 'black box' and often regarded as exogenous to the economy (Rosenberg 1982). Since neoclassical growth models were unable to explain lack of observed economic convergence, new or endogenous growth theories incorporated technological progress into their models (Barro, Sala-iMartin 1997; Grossman, Helpman 1991).

Technology can be to a certain part formalized in a specific set of rules, but it features also social and institutional dimensions difficult to transfer across people, firms and places (Polanyi 1966). Institutional economic theories emphasize specific combinations of social, cultural, political and other institutions and practices in the process of learning. Globalization, as a result of increased flows of goods and services and through activities of TNCs, makes exchange of codified knowledge much easier. However, tacit knowledge and context-dependent knowledge remains spatially sticky. This is illustrated by the literature on national and regional innovation systems, knowledge and learning economies (e.g. Cooke, Gomez Uranga, Etxebarria 1997; for an overview see Blažek 2012). Geographical and other forms of proximity (Boschma 2005) continue to regulate the growth process, contributing to the uneven distribution of production and income across regions and countries. Whether or not this unevenness can be 
tempered in the long run as new technologies become increasingly standardized and more easily transmitted and imitated through technology diffusion, remains an open question.

World trade rose by $6.2 \%$ per annum between 1950 and 2005 compared to the 3.8\% rise in world GDP (UN Comtrade 2012). There is little question that since the 1980s, trade flows have shifted, reflecting the rapid rise of developing economies around the world, particularly China. Not only has the volume of trade changed dramatically, so has the type of goods being moved around the global economy. This has prompted the development of a new set of trade models, built around heterogeneity of skills and technologies consistent with emerging patterns of offshoring (Grossman, Rossi-Hansberg 2008; Baldwin 2006). Traditionally, only complete goods where traded internationally. Now, production has been fragmented into different stages and countries are adding value within global value chains. This process has been called "task trade" (Grossman, Rossi-Hansberg 2008) or "vertical specialization" (Hummels, Klenow 2005). Imported inputs thus reduce the share of value added generated by individual exporters. For example the value added by Chinese producers in iPod, which was exported by China in 2006 for a unit price of 150 USD, was only 4 USD (Koopman, Wang, Wei 2008). Xu and Lu (2009) estimate that between 2000 and 2005 wholly owned foreign firms contributed by $63 \%$ and processing exports in general by $25 \%$ to China's rising export structure sophistication. Amiti and Freund (2008) confirm the role of processing trade in the increased skill content of China's manufacturing exports. In most studies, attention is given to China, the largest world exporter. Nonetheless, the situation might be also similar in other countries involved in processing trade like Malaysia.

On the other hand, exports do not take into account frugal innovation within emerging economies geared toward the domestic market, which are becoming an increasingly important source of their technological development. These innovations also contribute to technological competition with industries in developed countries. In recent years, emerging economies have witnessed growth across a series of indicators, including R\&D expenditures, patents or scientific publications (OECD 2013a). The global recession appears to have accelerated these trends. As developed countries grappled with fiscal austerity, many emerging economies, especially China, increased their R\&D investment. According to economic complexity, an indicator proposed by Hausmann et al. (2011), which measures the productive knowledge available in a country from the mix of products countries are able to produce, China and other emerging economies like Thailand and Malaysia are very complex. Nonetheless, this indicator is based on gross exports which might be misleading (see section 3). These economies are also relatively well positioned in the Global Competitiveness Report (Schwab, Sala-i-Martin, López-Claros 2012). This confirms rising technological capabilities in many emerging economies.

Offshoring production to emerging economies accompanied by intensified flows of trade and investment speed up the spread of technology and may contribute to economic growth and bigger technological convergence among countries. This is valid only for host economies, where sufficient absorptive capability of the advanced technologies is available, though (Borensztein, De 
Gregorio, Lee 1998). It has been proven that countries exporting more sophisticated goods have experienced faster economic growth (Fagerberg 1994; Hausmann, Hwang, Rodrik 2007). However, countries cannot just produce the type of goods they want, they move from the products they already create to similar products close to the productive knowledge they possess (Hausmann et al. 2011).

Globalization is largely seen to confer benefits on trading nations, but the gains from globalization are not absent costs, and those costs are not distributed evenly (Rigby, Breau 2008). Participation in global value chains, too, is often associated with many advantages, but does not necessarily mean higher gains. It is highly dependent on the domestic value added in exports and the position of domestic firms within the global value chains. While globalization typically means lower prices to consumers, it is often associated with a redistribution of productive resources that favors growth in some sectors and countries or regions, often at the expense of others. Within countries, globalization has markedly uneven impacts, too, as firms in different industries and workers in different occupations face new competitive pressures from places they could once ignore. Lowered transportation costs, improved communications technologies, and a recent marked upswing in technology transfer, is rapidly shifting the geography of competitive advantage (Baldwin 2006). Views on the impact of trade on employment and wages in rich countries differ, though. According to some scholars skill-biased technology is the main cause of rising wage inequality (Lawrence et al. 1993), others believe trade has a major impact on rising wage inequality (Feenstra, Hanson 1996; Grossman, Rossi-Hansberg 2006). At least within industrialized regions such as the EU, less-skilled workers in routine occupations seems to be most at risk, though, there are worries that due to innovation offshoring even highly skilled jobs in rich countries can be dismissed (Kemeny, Rigby 2012).

\section{Data and method}

\subsection{EXPY}

In this paper I will follow the measure of technological sophistication of exports - EXPY proposed by Hausmann, Hwang, Rodrik (2007). This measure shows the cross-country relationship between sophistication levels of exports and per capita income. Measuring technology has been problematic, since it is not directly observable in the economy. Several proxies have been used to measure differences in technological levels between countries. TFP, R\&D expenditures, patents and innovations are among the most common (Archibugi, Pianta 1996). However, using these proxies makes comparing countries at different stages of development particularly difficult since data may not be available for all countries, and they are often incomparable, e.g. because of different patent systems.

According to Hausmann, Hwang, Rodrik (2007) exports provide a relatively good measure of a country's technological capabilities. Production of goods in general reveals how an economy's knowledge assets are being used to leverage 
resources and generate wealth. Exports typically represent the portion of a country's production that is most efficient. Generally, only a limited number of companies export and those that do export tend to be larger and more productive than non-exporting companies (Bernard, Jensen 1999). Export data for most countries are widely available, and they are typically much more detailed than production data alone. Hausmann, Hwang, Rodrik (2007) proposed a measure that denotes product sophistication of a given product based on the per capita GDP of all countries exporting this type of product, counting on the assumption that rich countries export more sophisticated goods than poor countries.

On the other hand, international trade data and EXPY have several limitations. Firstly, the biggest limitation in assessing country's technological levels based on exports is the fact, that exports of countries often incorporate intermediate products that were produced in other countries. This so called foreign value added embodied in exports (FVA) differs significantly between countries and industries. In general small open economies produce less intermediate inputs domestically than large economies and are often heavily involved in international sourcing. Therefore, data on trade in value added will be included in the analysis (see below). Secondly, EXPY may not always reflect the quality of goods. However, there are no reliable methods for measuring product quality. A common proxy to measure quality is unit values of exports. According to Schott (2008), rich countries export to the US at higher unit prices, but differences in unit values also differ for other reasons than quality. Hallak and Schott (2011) found that changes in raw relative export prices can reflect both, quality differences and price competitiveness. Unit price differences were added to EXPY calculations by Kemeny (2011) in his TECH calculation. He found that TECH was highly correlated with EXPY.

In order to measure national technological levels, PRODY, a proxy for revealed productivity and EXPY values is computed for every year and for every country that exports to the EU15 (if trade and GDP data are available). Hausmann, Hwang, Rodrik (2007) used a shorter time period (1992-2003) and constant PRODY that ignores changes in the sophistication of products themselves over time. In contrast, I built EXPY for a significantly longer period (1984-2009) and my PRODY scores vary by product and by year. The method of calculating measures of technology for each country is outlined below.

First, for every product in the SITC revised 2 four-digit classification, a PRODY value is computed. PRODY is constructed as a weighted average of GDP per capita in all countries exporting the product. Countries are indexed by c, goods by $g, Y_{c}$ signifies per capita GDP, $\mathrm{X}_{\mathrm{c}}$ total exports of a country, $\mathrm{x}_{\mathrm{cg}}$ is the export value of good $\mathrm{g}$ for a country $\mathrm{c}$ :

$$
\text { PRODY }_{g}=\sum_{c}\left(\frac{\frac{x_{c g}}{X_{c}}}{\sum_{c}\left(\frac{x_{c g}}{X_{c}}\right)}\right) Y_{c}
$$

The numerator $\left(\frac{x_{c g}}{X_{c}}\right)$ denotes the value of good $g$ as a share of the total value of exports for a country $c$, the denominator $\sum_{c}\left(\frac{x_{c g}}{X_{c}}\right)$ aggregates the value 
shares of all the exporters of good g. Then, based on the PRODY scores, the technological sophistication for each country (EXPY) is computed as a weighted average of the PRODY:

$$
E X P Y_{c}=\sum_{g}\left(\frac{x_{c g}}{X_{c}}\right) P R O D Y_{g}
$$

where the weights are the value shares of the products in total exports of the country.

\subsection{D a t a}

The EXPY value is constructed based on trade data in the 4-digit Standard International Trade Classification (SITC), revision 2. Only merchandise exports are included in the dataset, exports of services are excluded. The trade data is taken from two sources. Feenstra, Lipsey (2005) prepared bilateral trade dataset - World Trade Flows (WTF) for the years 1984 up to 2000. Since data for recent years were not available, data from UN COMTRADE for 2001-2009 (UN Comtrade 2012) were used and adjusted in a similar way as in WTF.

I give primacy to the data from importers of generally better quality, especially when reported from EU countries. In order to account for inflation, data for all years are denominated in 2005 US dollars. The GDP per capita in PPP comes from the Penn World Tables, version 7.0 (Heston, Summers, Aten 2011). If GDP per capita was missing for a given year and country, the country was removed from the calculations. The number of countries for which EXPY was calculated ranges from 120 and 150 over the period 1984-2009.

Since EXPY is based on exports of individual countries, the results might be biased due to the assumption the products exported have been completely produced in the economy. Thus, they do not capture the fragmentation of production within value chains. In recent years several datasets have been developed, which are based on input-output tables. These datasets capture trade in intermediate inputs and thus allow assessing the domestic/foreign value added embodied in exports. Since they are only available for some countries and at highly aggregated product level they cannot be used to calculate EXPY. Despite of that data from OECD-WTO initiative Trade in Value Added - TiVA (OECD 2013a, b) will be used to demonstrate the differences between gross exports and domestic value added exports. Although these data are available only for several years between 1995 and 2009, they can give a view on how important is foreign value added in countries' exports. The results will be further compared to EXPY calculated based on BACI world trade database (CEPII 2012). This database covers all international trade flows and in case of China EXPY is also calculated separately for processing trade and ordinary trade and even for domestic and nondomestic firms.

Trade in services is not included, because data on exports of services are not available in detailed classification and are therefore much less reliable. Although trade in services is of growing importance, most countries exporting advanced services will probably also export more sophisticated goods. At the same time, it is estimated that $40 \%$ of the total value added embodied in 
Table 1 - Highest and lowest PRODY

\begin{tabular}{|c|c|c|c|}
\hline \multicolumn{2}{|l|}{ Lowest PRODY* } & \multicolumn{2}{|l|}{ Highest PRODY* } \\
\hline Product & PRODY* & Product & PRODY* \\
\hline $\begin{array}{l}\text { Sisal, agave fibres, raw or processed } \\
\text { but not spun, and waste }\end{array}$ & 1,084 & $\begin{array}{l}\text { Uranium depleted in U235, thorium, } \\
\text { and alloys, nes; waste and scrap }\end{array}$ & 31,767 \\
\hline $\begin{array}{l}\text { Jute, other textile bast fibres, nes, raw, } \\
\text { processed but not spun }\end{array}$ & 1,087 & Polyvinylacetate & 31,411 \\
\hline $\begin{array}{l}\text { Natural gums, resins, lacs and } \\
\text { balsams }\end{array}$ & 1,205 & $\begin{array}{l}\text { Bookbinding machinery; parts thereof, } \\
\text { nes }\end{array}$ & 30,688 \\
\hline $\begin{array}{l}\text { Fabrics, woven of jute or other textile } \\
\text { bast fibres of heading }\end{array}$ & 1,252 & Printing inks & 30,201 \\
\hline Groundnut (peanut) oil & 1,354 & Acyclichydrocarbons & 29,243 \\
\hline
\end{tabular}

Source: Feenstra, Lipsey (2005); UN Comtrade (2012), own calculations

* Based on average PRODY from 1984 to 2009

manufacturing exports originate from service sector (OECD 2013b). Nevertheless, Indian IT companies are exporting advanced services, but India scores low on the export of more sophisticated goods. Thus, for India the EXPY might underestimate the technological level of a country.

For the calculation of EXPY, exports to the EU15 have been used in order to assess the position of possible competitors of the EU members from emerging economies. So far exports to the US have been used in most studies. Using exports to the EU enables me to compare EXPY to studies based on exports to the US or to the whole world. The technological sophistication of exports of the EU15 members is not included, since intra-EU trade is not involved. Although the EU now has 27 member states, until the mid-2000s there were only 15 members. Increasing the number of the states whose exports were evaluated in the observed period could significantly change the calculation of EXPY. I also calculated EXPY based on exports to the EU27 for several years of the observed period in order to see if the addition of new member states had a significant impact on results. Apart from a few small countries the differences in EXPY based on calculations for the EU27 and EU15 were negligible and correlation coefficients for the EXPY measures across the years examined ranged from 0.97 to 0.99 . Trade policies of the EU can have an impact on the exports of individual countries and the type of goods these countries export to the EU. Similar results for EXPY calculated for EU15 and EU27 before the EU enlargement indicate that this impact is likely small.

Table 1 shows five products with the lowest and highest PRODY. Primary products like sisal, jute, tea, natural gums and oil, which are an important part of the export basket of the least developed countries like Bangladesh or Sudan, score the lowest PRODY. In contrast, goods with the highest PRODY include polyvinyl acetate or bookbinding machinery. Main exporters of polyvinyl acetate are Switzerland and the US, bookbinding machinery is exported by Switzerland or Japan. 


\section{Results}

4.1. General differences in technological levels between countries

During the 26 years examined, significant changes in the patterns of exports to the EU15 have occurred. While the share of exports from the USA fell from $29 \%$ to $15 \%$ and from Japan from $13 \%$ to 5\%, exports from China have risen from $3 \%$ to $18 \%$. As expected, high-income countries have high EXPY scores while the lowest EXPY scores are recorded by the least developed countries (see Table 2).

Qatar has the highest EXPY in most years. This is understandable, since GDP per capita in 2009 was almost 160,000 USD and most products exported by Qatar have relatively high PRODY. For oil-exporting countries like Saudi Arabia or Algeria, the EXPY overestimates their technological progress, because apart from oil and gas with their extremely volatile prices, they export mostly machinery and chemical products with high PRODY. However, in this paper I focus mainly on emerging economies. The United States, Japan and Switzerland have managed to maintain their technological leadership throughout the period. Singapore has shifted from $11^{\text {th }}$ to $3^{\text {rd }}$ position since the mid-1980s thanks to the type and quality of goods it exports and its increased income level. Among the countries at the bottom of the EXPY ranking are mostly those from South-East Asia and Africa. Least developed African countries are not included in Table 2 since they only export to the EU a limited number of product varieties with low value.

Firstly, I will examine differences in technological levels changed within the exporters to the EU over time and compare them to other data. The mean EXPY has almost doubled due to overall technological progress (see Table 3). The median is below mean, thus most countries exports are less sophisticated

Table 2 - Countries with highest and lowest EXPY*

\begin{tabular}{|llll|llll|}
\hline \multicolumn{2}{|l|}{ Highest EXPY } & \multicolumn{4}{l|l}{ Lowest EXPY } \\
\hline \multicolumn{2}{|l|}{ Avg. 1984-1986 } & \multicolumn{2}{l|}{ Avg. 2007-2009 } & & Avg. 1984-1986 & \multicolumn{2}{l|}{ Avg. 2007-2009 } \\
\hline Japan & 16,961 & Qatar & 52,379 & Cambodia & 1,783 & Ghana & 4,192 \\
Iceland & 16,578 & Trinidad Tbg & 41,468 & Uganda & 2,369 & Ethiopia & 4,363 \\
Switzerland & 15,909 & Singapore & 28,849 & Bangladesh & 2,605 & Kenya & 4,543 \\
New Zealand & 15,016 & Algeria & 26,471 & Guatemala & 2,647 & Uganda & 4,891 \\
USA & 14,677 & Egypt & 23,784 & Madagascar & 2,675 & Honduras & 5,038 \\
\hline Qatar & 14,096 & Switzerland & 22,266 & Papua N.Guin & 2,675 & Papua N.Guin & 5,186 \\
Norway & 13,782 & Nigeria & 21,581 & Kenya & 2,844 & Guatemala & 5,794 \\
Saudi Arabia & 13,782 & USA & 21,435 & Tanzania & 2,914 & Tanzania & 5,910 \\
Untd Arab Em & 13,749 & Japan & 20,157 & Cote Divoire & 2,930 & CoteDivoire & 5,948 \\
Canada & 13,456 & New Zealand & 19,690 & Vietnam & 2960 & Paraguay & 6,355 \\
\hline
\end{tabular}

Source: Feenstra, Lipsey (2005), UN Comtrade (2012), own calculations

* Only countries that export at least 30 product varieties and their share in export value is higher than $0,02 \%$ were included 
Table 3 - Descriptive statistics of EXPY

\begin{tabular}{|c|c|c|c|c|c|}
\hline & 1984 & 1990 & 1997 & 2003 & 2009 \\
\hline Observations & 120 & 126 & 148 & 148 & 150 \\
\hline Minimum & 1,710 & 1,331 & 1,289 & 1,292 & 1,851 \\
\hline Maximum & 22,317 & 26,442 & 27,215 & 34,640 & 56,034 \\
\hline Bottom 5 & 1,890 & 1,837 & 1,899 & 2,324 & 2,472 \\
\hline Top 5 & 17,460 & 19,099 & 21,331 & 22,090 & 40,792 \\
\hline Mean & 6,278 & 7,698 & 8,449 & 9,439 & 11,983 \\
\hline Median & 2,960 & 3,566 & 3,591 & 3,705 & 4,955 \\
\hline Standard deviation & 3,954 & 4,444 & 4,697 & 4,798 & 7,538 \\
\hline Gini Coefficient & 0.34 & 0.32 & 0.31 & 0.28 & 0.30 \\
\hline Coefficient of variation & 0.54 & 0.53 & 0.46 & 0.42 & 0.45 \\
\hline Range of top 5 to bottom 5 & 9.2 & 10.4 & 11.2 & 9.5 & 16.5 \\
\hline
\end{tabular}

Source: Feenstra, Lipsey (2005), UN Comtrade (2012), own calculations

than world average. The range between the five countries with highest and lowest EXPY scores has risen by $80 \%$ from 9.2 to 16.5 . Whereas the average EXPY of the top 5 countries is twice as high in 2009 than in 1984, the average EXPY of the bottom five economies has remained relatively stable. The least developed economies have seen their EXPY level stagnate in the past three decades. However, no country has suffered absolute decline in the index of technological sophistication.

Despite the fact that the range of EXPY between the top and bottom five economies has increased, both the Gini coefficient and coefficient of variation of EXPY declined slightly for all importers to the EU between 1984 and 2009. This is proof of minor narrowing of inequality in technological levels between exporters to the EU.

Kernel density estimates provide another way of examining the distribution of EXPY values over time. Figure 1 reports the distribution of EXPY values for all exporters to the EU in 1984, 1990, 1997, 2003 and 2009. In Figure 1 the curves are highly skewed to the right, thus the majority of countries have low EXPY and only a few countries are technologically highly sophisticated. EXPY scores have risen within the 26 years, while the distribution has smoothened. The peak of the curve has shifted to the right and broadened. Also, its density value has dropped significantly. Thus there are now more countries with medium sophistication levels with EXPY between 10,000 and 20,000, especially among post-communist countries and Asian emerging economies.

The gap between traditional technological leaders like Japan, USA and Switzerland and China, India and many other emerging economies has decreased in the past 26 years. The increase of EXPY for these countries was gradual with minor slowdowns after 2001 and 2007. The ranking of China and India between 1984 and 2009 has improved (even after accounting for the increased number of countries in the observed period). Improvements can also be observed in case of other emerging economies, especially in Thailand, Malaysia and the Philippines and also Mexico and Vietnam. The position of Turkey and Hong Kong is stable, whereas relative technological levels of South Africa and Brazil fell. However, China is still at the $34^{\text {th }}$ position, India $60^{\text {th }}$ and Brazil $74^{\text {th }}$ 


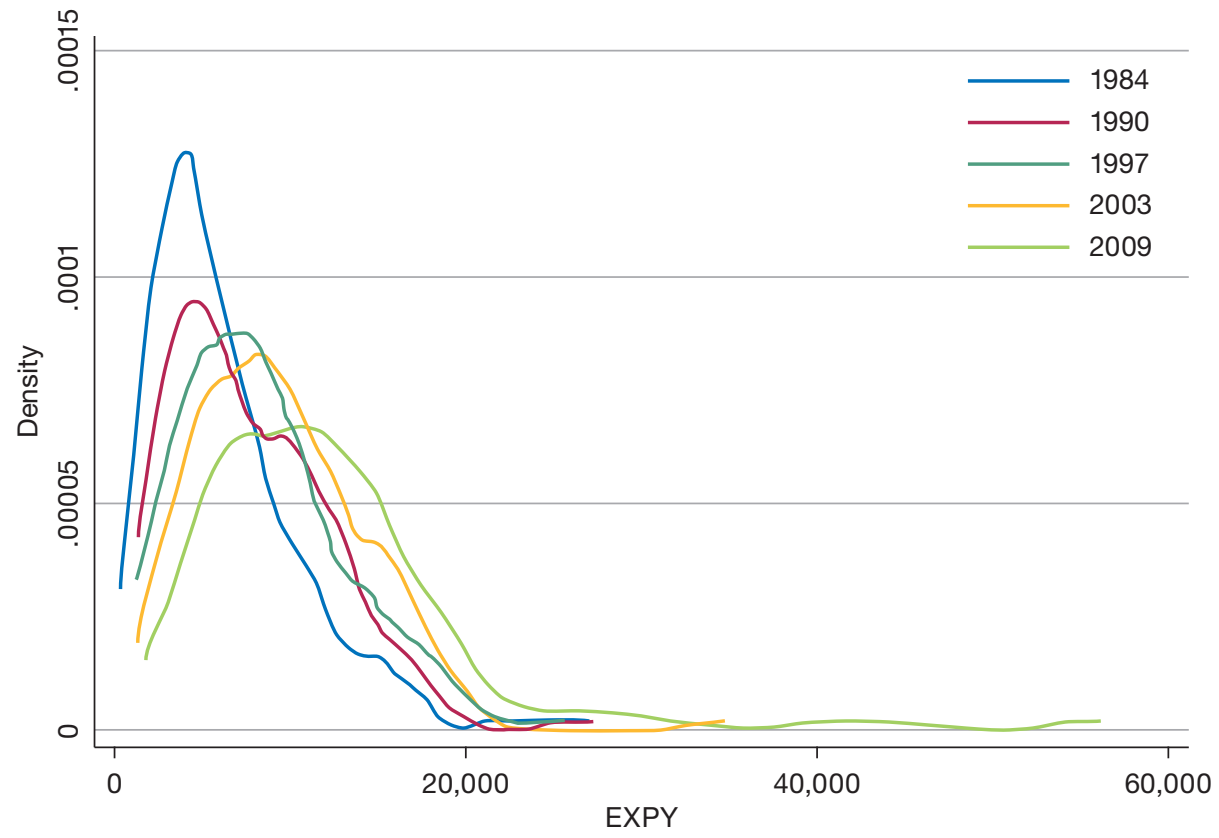

Fig. 1 - Kernel plot for EXPY in 1984, 1990, 1997, 2003, 2009. Source: Feenstra, Lipsey (2005), UN Comtrade (2012), own calculations

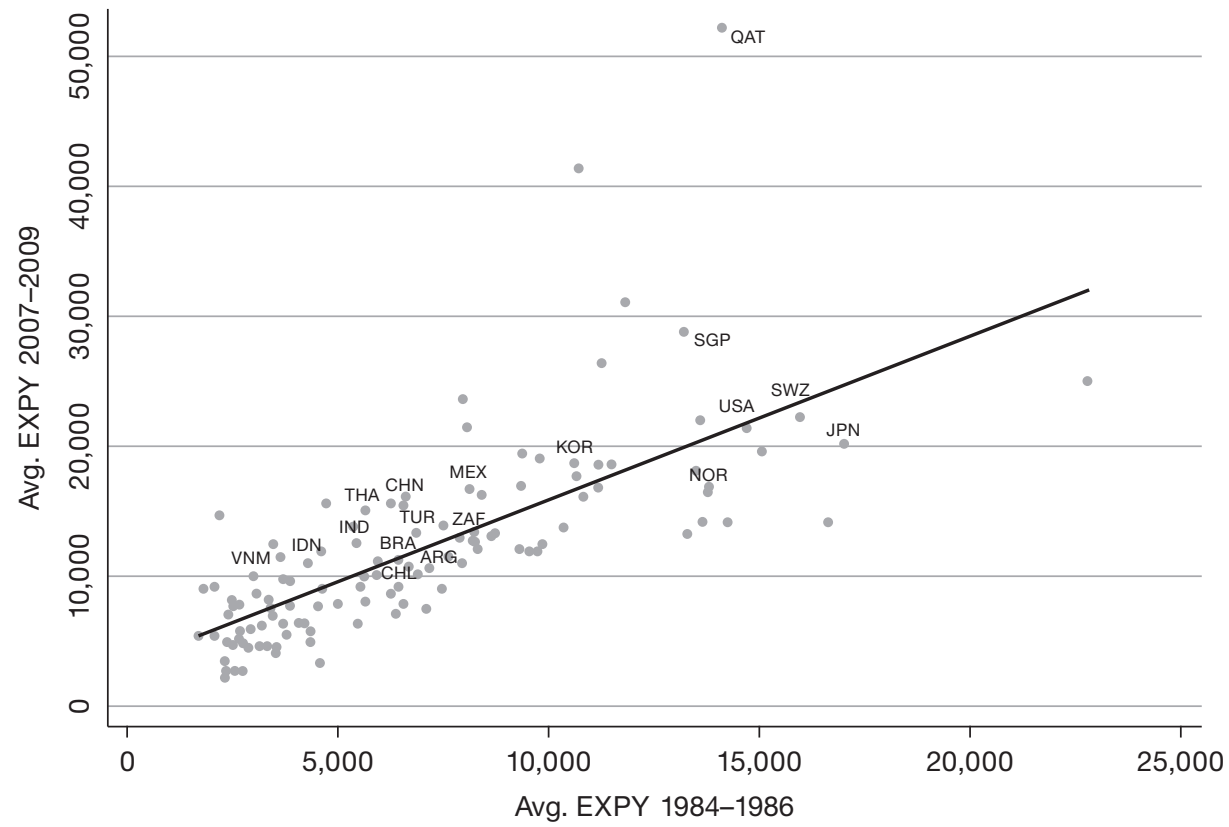

Fig. 2 - Scatter graph for EXPY 1984-1986 and EXPY 2007-2009. Source: Feenstra, Lipsey (2005), UN Comtrade (2012), own calculations 
Table 4 - Foreign value added share of gross exports in selected economies in 1995 and 2009

\begin{tabular}{|c|c|c|c|c|c|c|c|c|c|c|c|c|}
\hline Country & Year & $\begin{array}{l}\text { శ్ } \\
\text { О్. } \\
\text { స్ }\end{array}$ & 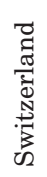 & 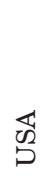 & 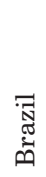 & 丞 & $\underset{\pi}{\tilde{\Xi}}$ & $\begin{array}{l}\frac{\pi}{\pi} \\
\frac{\pi}{2} \\
\frac{\pi}{\pi} \\
\sum\end{array}$ & 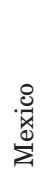 & 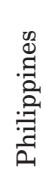 & 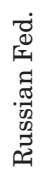 & 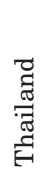 \\
\hline \multirow{2}{*}{$\begin{array}{l}\text { FVA share of } \\
\text { gross exports }(\%)\end{array}$} & 1995 & 7 & 23 & 8 & 10 & 12 & 10 & 40 & 27 & 31 & 11 & 30 \\
\hline & 2009 & 15 & 28 & 11 & 9 & 33 & 22 & 38 & 30 & 38 & 7 & 35 \\
\hline
\end{tabular}

Source: OECD (2013)

based on average EXPY 2007-2009 of all 150 economies. Among other emerging economies, Mexico is doing best at $28^{\text {th }}$ position, followed by Philippines $\left(33^{\text {rd }}\right)$, Malaysia $\left(35^{\text {th }}\right)$ and Thailand $\left(38^{\text {th }}\right)$.

In order to follow changes of EXPY over time, I plotted initial average EXPY scores of countries against their current EXPY in Figure 2. This provides an indicator of correlation, thus for countries on the fitted line the EXPY values at the beginning of the period perfectly predict their technological level at the end of the period. For countries below the line, technological sophistication of exports dropped relative to other countries and countries above the line have higher technological levels than predicted from their initial position. China, India, Thailand, Mexico or Indonesia have higher technological levels than predicted from their initial position. Traditional technological leaders like the USA, Switzerland or Japan developed at roughly the same pace as the world average. The Latin American countries witnessed relative decline.

As was already mentioned in previous sections, the exports can embody intermediates produced in other countries. Especially in case of emerging economies, where many products are only assembled though the complete value of the product is attributed to them (e.g. well known example of Chinese domestic value added embodied in iPhones). Here I present the foreign value added embodied in exports of selected developed and emerging economies according to TiVA data (see Table 4). Emerging economies that are most technologically developed based on EXPY (Mexico, Philippines, Malaysia, Thailand and China) have the highest share of FVA which has increased over time. On the other hand, Brazil or Russia have low share of FVA. These countries export mostly commodities which contain no FVA. At the level of individual industries the differences are even bigger, e.g. in Electrical and optical equipment the FVA exceeds 50\% in most of the emerging economies. And products from this industry belong to those with relatively high PRODY. This indicates that EXPY can significantly overestimate technological levels of countries that have strong participation in global value chains. As the sophistication of exports of emerging economies increased over time, so did the foreign value added share embodied in these exports. 


\subsection{Comparison to other studies}

Technological sophistication of exports has been followed also in other studies. These studies used in most cases exports to the US (e.g. Kemeny 2011; Hausmann, Hwang, Rodrik 2007) or to the whole world (CEPII 2012). Based on exports to the whole world (CEPII 2012) the highest EXPY among emerging economies is witnessed by Malaysia, Philippines, Mexico and China. Even after excluding processing trade and exports by foreign firms, China's exports are more sophisticated than for example exports from Israel, Portugal or Greece. Nonethless, even exports of Chinese firms that do not fall under processing trade can contain significant share of FVA. The EXPY is significantly lower for Indonesia and Brazil. EXPY for India and Latin American countries is relatively low.

According to exports to the United States between 1992 and 2003 Hausmann, Hwang, Rodrik (2007) found relatively high EXPY in contrast to per capita income in case of India, China and Mexico. On the other hand Kemeny (2011), who used unit values in his TECH index, found that for most technological laggards the EXPY rose due to the fact that they started to export new types of products while dropping the ones with the lowest revealed productivity. Technological upgrading in China and India was below the global average and China experienced quality downgrading. However, Philippines and Malaysia, as well as a number of post-communist transition economies, have upgraded their technological sophistication. Amiti and Freund (2008), too, found that when processing trade is excluded, the skill content of China's manufacturing exports has not changed, export growth was mainly due to intensive margin (growth in existing, not new varieties) and export prices to the US between 1997 and 2005 fell by $1.6 \%$. Xu and Lu (2009) confirmed the role of processing trade and foreign companies in rising sophistication of Chinese exports. Hallak and Schott (2011) who measured quality based on observed export prices combined with trade balances of countries, found that economies with the highest increases in quality rankings (among 43 countries) were Singapore, Indonesia and Malaysia. According to them, China has exceptional economic growth, but almost no change in quality.

\section{Conclusion}

In recent years we have witnessed rising technological capabilities in many emerging economies, especially in China and some Asian countries. R\&D expenditures, the numbers of patents, scientific papers and graduates are increasing at a relatively fast pace in these economies. These trends raise a series of questions. Are technological gaps between countries shrinking? How successful are emerging economies and can they catch up to technological leaders?

Recently developed indicator - the EXPY proposed by Hausmann, Hwang, Rodrik (2007) - uses exports to assess technological levels of countries. The aim of this paper was to examine whether the EXPY can be used to explore the technological capabilities of countries. Firstly the EXPY was calculated based on exports to the EU between 1984 and 2009. In terms of EXPY, the gap 
between the least and the most technologically advanced countries has risen, but the overall distribution has narrowed. Most countries remain trapped at the lower end of the distribution of global technology. At the same time, emerging economies in particular have made significant progress and have shifted to medium levels of technological sophistication. Major improvements were achieved by Malaysia, Philippines and Mexico. China and India improved their position among other countries, whereas South Africa and Brazil have slightly declined. Developed countries on the whole show a slower pace of technology development, but they have maintained their technological leadership. Other relevant studies too found high technological capabilities in Malaysia, Philippines or Mexico. In case of China the conclusions differ. According to several studies focused on processing trade and/or unit values, technological upgrading of China was attributable to processing trade. The situation in other emerging economies can be similar as in China, though, if the "type" of exports would be explored in detail.

Main limitation of EXPY is thus the fact, that countries can export goods that are only assembled and contain intermediate inputs produced in other countries. New datasets based on input-ouput models can overcome this limitation, but they are only available at highly aggregated levels. Therefore, I looked at the share of foreign value added embodied in exports of countries. In emerging economies that have made biggest progress in terms of EXPY like Mexico, Malaysia and also China the foreign value added share of exports is higher than $30 \%$. This number increases over time and also in industries where products are associated with higher EXPY. Therefore, EXPY can give a misleading picture of technological upgrading, if countries get more involved in global value chains. EXPY thus needs to be interpreted with caution and cannot serve as a reliable indicator of technological capabilities of countries on its own.

Despite the doubts about China's technological capabilities based on its exports, their increasing number of world patents, contributions to top scientific papers or progress in aerospace industry show the opposite. For the EU and other developed countries there is no choice but to move up the quality ladder in order to keep ahead of the competition from low-wage countries.

Measuring technology will remain problematic. Yet, new data sources are being continuously prepared, especially those based on input-output models. If this data were available at more disaggregated levels, they could be incorporated into the calculations of EXPY and give a more reliable insight. Future research should therefore focus on using this data and possibly combine it with other data on R\&D and innovations.

\section{References:}

ALTENBURG, T., SCHMITZ, H., STAMM, A. (2008): Breakthrough? China's and India's Transition from Production to Innovation. World Development 36, pp. 325-344.

AMITI, M., FREUND, C. (2008): An anatomy of China's export growth. Global Implications of China's Trade. Investment and Growth Conference, IMF Research Department, April, $6,2008$.

ARCHIBUGI, D., PIANTA, M. (1996): Measuring technological through patents and innovation surveys. Technovation 16, pp. 451-468. 
BALDWIN, R. (2006): Globalization: the great unbundling(s). Finnish Prime Minister's Office for EU Presidency, www.hei.unige.ch/baldwin/.

BARRO, J., SALA-I-MARTIN, X. (1997): Technological diffusion, convergence, and growth. Journal of Economic Growth, 2, pp. 1-26.

BERNARD, A.B., JENSEN, B.J. (1999): Exceptional exporter performance: cause, effect, or both? Journal of international economics, 47, No. 1, pp. 1-25.

BLAŽEK, J. (2012): Regionální inovační systémy a globální produkční sítě - dvojí optika na zdroje konkurenceschopnosti v současném světě. Geografie, 117, No. 2, pp. 209-233.

BOSHMA, R. (2005): Proximity and innovation. A critical assessment. Regional Studies 39, pp. $61-74$.

BORENSZTEIN, E., De GREGORIO, J., LEE, J.W. (1998): How does foreign direct investment affect economic growth? Journal of International Economics, 45, No. 1, pp. 115-135.

CEPII (2012): The CEPII Sophistication measure Dataset. <http://www.cepii.fr/anglaisgraph/ $\mathrm{bdd} /$ sophistication.htm> (20. 3. 2013).

COOKE, P., GOMEZ URANGA, M., ETXEBARRIA, G. (1997): Regional innovation systems: Institutional and organisational dimensions. Research policy, 26, No. 4, pp. 475-491.

FAGERBERG, J. (1994): Technology and International Differences in Growth Rates. Journal of Economic Literature 32, pp. 1147-1175.

FEENSTRA, R., HANSON, G. (1996): Globalization, outsourcing, and wage inequality. American Economic Review 86, pp. 240-245.

FEENSTRA, R., LIPSEY, R. (2005): World trade flows, 1962-2000. Center for International Data, Institute of Governmental Affairs, UC Davis, pp. 1-63.

GERTLER, S.T. (2007): Tacit knowledge in production systems: how important is geography? In: Polanske, R.K. (ed.): The economic geography of innovations. Cambridge University Press, pp. 87-112.

GROSSMAN, G., HELPMAN, E. (1991): Innovation and Growth in the Global Economy. MA, MIT press, Cambridge, $384 \mathrm{pp}$.

GROSSMAN, G., ROSSI-HANSBERG, E. (2008): Trading tasks: A simple theory of offshoring. NBER Working Paper 12721, pp. 1978-1997.

HALLAK, J.C., SCHOTT, P.K. (2011): Estimating Cross-Country Differences in Product Quality. The Quarterly Journal of Economics 126, pp. 417-474.

HAUSMANN, R., HWANG, J., RODRIK, D. (2007): What you export matters. Journal of Economic Growth 12, pp. 1-25.

HAUSMANN, R., HIDALGO, C., BUSTOS, S., COSCIA, M., CHUNG, S., JIMENEZ, J., YILDRIM, M. (2011): The atlas of economic complexity. MA, Puritan Press, Cambridge, $364 \mathrm{pp}$.

HESTON, A., SUMMERS, R., ATEN, B. (2011): Penn World Table Version 7.0, Center for International Comparisons of Production, Income and Prices at the University of Pennsylvania, May 2011, $60 \mathrm{pp}$.

HUMMELS, D., KLENOW, P.J. (2005): The variety and quality of a nation's exports. American Economic Review, pp. 704-723.

JAFFE, A.B., TRAJTENBERG, M., HENDERSON, R. (1993): Geographic localization of knowledge spillovers as evidenced by patent citations. The Quarterly Journal of Economics 108, pp. 577-598.

KEMENY, T. (2011): Are Technology Gaps Growing or Shrinking in the Age of Globalization? Journal of Economic Geography, 11, pp. 1-35.

KEMENY, T., RIGBY, D. (2012): Trading away what kind of jobs? Globalization, trade and tasks in the US economy. Review of World Economics, 148, pp. 1-16.

KOOPMAN, R., WANG, Z., WEI, S. (2008): How Much of Chinese Exports is Really Made In China? Assessing Domestic Value-Added. No. w14109. National Bureau of Economic Research, pp. 1-51.

KRUGMAN, P. (1991): Increasing returns and economic geography. Journal of Political Economy, 99, pp. 483-499.

LAWRENCE, R., SLAUGHTER, M., HALL, R., DAVIS, S., TOPEL, R. (1993): International trade and American wages in the 1980s: Giant sucking sound or small hiccup? Brookings Papers on Economic Activity. Microeconomics, 2, pp. 161-226. 
LUCAS Jr, R.E. (1988): On the mechanics of economic development. Journal of monetary economics, 22 , No. 1, pp. 3-42.

OECD (2013a): OECD Science, Technology and R\&D Statistics, < http://www.oecd-ilibrary. org/science-and-technology/data/oecd-science-technology-and-r-d-statistics_strd-dataen;jsessionid=044fl9bg438q.x-oecd-live-02> (5. 4. 2013).

OECD (2013b): OECD-WTO Trade in Value Added (TiVA), <http://stats.oecd.org/index. aspx?queryid=47807> (5. 1. 2015).

POLANYI, M. (1966): The tacit dimension. Doubleday, New York, 128 pp.

RIGBY, D., BREAU, S. (2008): Impacts of Trade on Wage Inequality in Los Angeles: Analysis Using Matched Employer-Employee Data. Annals of the Association of American Geographers, 98, pp. 920-940.

ROMER, P.M. (1990): Endogenous technological change. Journal of Political Economy, 98, pp. 71-102.

ROSENBERG, N. (1982): Inside the Black Box: Technology and Economics. Cambridge University Press, $320 \mathrm{pp}$.

SAXENIAN, A. (1996): Regional advantage: culture and competition in Silicon Valley and Route 128. Harvard University Press, Cambridge, Mass, $240 \mathrm{pp}$.

SCHOTT, P.K. (2008): The relative sophistication of chinese exports. Economic Policy, 23, pp. 5-49.

SCHWAB, K., SALA-I-MARTIN, X., LÓPEZ-CLAROS, A. (2012): The global competitiveness report 2012-2013. World Economic Forum. <http://www3.weforum.org/docs/WEF_ GlobalCompetitivenessReport_2012-13.pdf> (1. 2. 2013).

SCHUMPETER, J.A. (1947): Capitalism, socialism, and democracy. Harper \& Brothers, New York, London, $431 \mathrm{pp}$.

SOLOW, R.M. (1956): A Contribution to the Theory of Economic Growth. The Quarterly Journal of Economics, 70, pp. 65-94.

UN COMTRADE (2012): United Nations. New York, http://comtrade.un.org/ (12. 7. 2012).

XU, B., LU, J. (2009): Foreign direct investment, processing trade, and the sophistication of China's exports. China Economic Review, 20, pp. 425-439.

Shrnutí

\section{MOHOU BÝT EXPORTY POUŽITY JAKO INDIKÁTOR TECHNOLOGICKÝCH KAPACIT ZEMÍ?}

Článek je zaměřen na technologickou vyspělost výrobků exportovaných do EU. Rychlý ekonomický růst rozvíjejících se ekonomik, zejména Číny a mnoha dalších asijských ekonomik, který je spojen s nárůstem jejich inovačních a technologických kapacit, vyvolává otázky týkající se udržitelnosti dominantního postavení vyspělých zemí. V oblasti inovačního potenciálu rozvíjejících se ekonomik panují spory. Díky globalizaci a větší ekonomické integraci je usnadněn transfer technologií, na druhou stranu znalosti, především ty nekodifikovatelné, jsou geograficky vázané a málo mobilní.

Technologická vyspělost zemí se obtížně měří, protože technologie nelze přímo pozorovat. Běžné indikátory jako výdaje na VaV, patenty či inovace mají řadu omezení, např. nejsou vždy dostupné a jsou obtížně srovnatelné u zemí v různé fázi ekonomického rozvoje. V článku využívám poměrně nový ukazatel EXPY. EXPY vyjadřuje vztah mezi technologickou vyspělostí exportů a příjmem na obyvatele a je spočtena pro jednotlivé země. Na základě detailních dat o mezinárodním obchodě (4místná klasifikace SITC) je stanovena technologická vyspělost zemí od roku 1984 do roku 2009.

Cílem článku je zjistit, zda poměrně nový indikátor technologické vyspělosti - EXPY navržený Hausmannem, Hwangem, Rodrikem (2007) lze použít pro měření technologických kapacit zemí. V článku je tedy zaprvé zjištováno, jaké jsou ve sledovaném období rozdíly $\mathrm{v}$ technologické úrovni mezi zeměmi, a tyto výsledky jsou porovnány s dalšími daty, aby bylo možné ověřit vypovídací schopnost indikátoru EXPY. Zadruhé porovnávám zjištěnou technologickou vyspělost zemí s ostatními studiemi používajícími EXPY. 
Na základě EXPY bylo zjištěno, že technologické rozdíly mezi nejvyspělejšími a nejméně vyspělými zeměmi se mírně zvýšily, došlo ale k většímu rozvrstvení. Zatímco nejchudší země zůstaly na stejné úrovni, řada ekonomik se posunula na střední úroveň technologického rozvoje, zejména rychle se rozvíjející ekonomiky. Vyspělé země si udržely vedoucí postavení, ačkoliv se tento náskok mírně snížil. Z rychle se rozvíjejících ekonomik zaznamenaly největší pokrok Malajsie, Filipíny a Mexiko. Ćína i Indie zlepšily svou pozici mezi ostatními zeměmi, zatímco JAR a Brazílie zaznamenaly pokles. Při srovnání EXPY na základě exportů do EU s jinými studiemi, jež vycházely z exportů do USA nebo do celého světa, byly závěry velmi podobné. I další studie potvrzují velké technologické kapacity Malajsie, Filipín nebo Mexika. Největší rozdíl je však v případě Číny. Podle některých studií, jež zohledňují tzv. processing trade a/nebo jednotkové ceny, souvisí technologický vzestup Cíny zejména s tzv. processing trade. Je možné, že situace by byla podobná i v dalších rychle se rozvíjejících ekonomikách, pokud by byla větší pozornost věnována struktuře exportů.

Hlavním omezením indikátoru EXPY je tedy skutečnost, že země mohou exportovat výrobky, které pouze smontují z meziproduktů pocházejících z jiných zemí. Nové databáze vycházející z tabulek „input-output“ mohou toto omezení překonat, jsou však dostupné pouze za úroveň jednotlivých odvětví. Z tohoto důvodu jsem se zaměřila na podíl zahraniční přidané hodnoty v exportech jednotlivých zemí. V rychle se rozvíjejících se ekonomikách převyšuje podíl zahraniční přidané hodnoty v exportech $30 \%$. Navíc toto číslo se v průběhu let zvyšuje a je také mnohem vyšší v odvětvích, které zahrnují produkty spojené s vyšší EXPY. EXPY tím pádem může podávat zkreslený obraz narůstajících technologických kapacit, $\mathrm{v}$ případě že země exportují výrobky s velkým podílem zahraniční přidané hodnoty. EXPY je tedy nutné používat $\mathrm{s}$ vědomím výše uvedených omezení a nelze jej použít jako spolehlivý indikátor technologické vyspělosti zemí sám o sobě.

I přes pochyby o technologických kapacitách Číny dle jejích exportů svědčí narůstající počet světových patentů, příspěvků ve špičkových vědeckých časopisech nebo pokroky v kosmickém průmyslu o opaku. Pro EU a další vyspělé země je technologický pokrok jedinou možností, jak čelit konkurenci rychle se rozvíjejících ekonomik. Měření technologií zůstává problematické. Pokud by byla dostupná nová data z tabulek „input-output“ v detailnější úrovni, mohly by být využity při výpočtu EXPY.

Obr. 1 - Jádrové odhady pro EXPY v letech 1984, 1992, 1997, 2003 a 2009

Obr. 2 -Korelační diagram pro hodnoty EXPY v letech 1984-1986 a 2007-2009

Authors' affiliation: University of Economics, Faculty of international relations, Department of World Economy, nám. W. Churchilla 4, 13067 Praha 3, Czechia; e-mail: jana.vlckova@vse.cz.

Initial submission, 26 April 2013; final acceptance 27 February 2015.

\section{Please cite this article as:}

VLČKOVÁ, J. (2015): Can exports be used as an indicator of technological capabilities of countries? Geografie, 120, No. 3, pp. 314-329. 